\title{
A Comparison of the Brightness of Country and City High-School Children
}

\author{
James H. Hinds
}

To cite this article: James $\mathrm{H}$. Hinds (1922) A Comparison of the Brightness of Country and City High-School Children, The Journal of Educational Research, 5:2, 120-124, DOI: 10.1080/00220671.1922.10879238

To link to this article: http://dx.doi.org/10.1080/00220671.1922.10879238

册 Published online: 15 Dec 2014.

Submit your article to this journal $\pi$

Q View related articles $\sqsubset$

4 Citing articles: 2 View citing articles 


\title{
A COMPARISON OF THE BRIGHTNESS OF COUNTRY AND CITY HIGH-SCHOOL CHILDREN
}

\author{
JAmes H. Hinds \\ State Board for Vocational Education, Austin, Texas
}

\section{Purpose and Method}

The results here reported came to light in an investigation whose general purpose was to inquire into the relationship existing between general intelligence, as determined by group mental tests, and the choice of and success in high-school subjects. Comparisons were especially desired between groups choosing vocational subjects and those choosing non-vocational subjects. Pupils having the privilege of electing Latin, Spanish, French, vocational agriculture, home economics, and trades and industries were selected for the tests. A vocational and a non-vocational group were chosen from each school. Tests were made in practically every type of school in Texas, both white and colored, offering electives in the Smith-Hughes vocational subjects and in some non-vocational subject. Some of the non-vocational subjects were offered as electives only in the larger city schools. The fact that the Latin students, for example, were not equally distributed among the different types of schools may account for the high score attained by this group.

Several of the groups were taken from a city system. To offset the city system, however, groups were also chosen from four rural schools located in the open country some distance from the railroad. Groups were likewise included from two small town schools which had, respectively, seven and nine teachers, and were located in towns of about $\mathrm{I}, 000$ inhabitants. The six remaining schools were located in towns somewhat larger, having from twelve to twenty teachers. All of the latter had some kind of college affiliation.

In each case the hearty cooperation of the principal and teachers was first obtained. If they were at all skeptical of the value of mental tests, the school was passed by. The Otis Group 
Test, Form A, was used. The test conditions were made as nearly uniform as possible, and the tests were administered strictly according to the procedure prescribed by the author. In making comparison, the Otis* index of brightness was used. Medians and other values were computed by the methods suggested by Rugg.*

\section{RESULTS}

It is evident from a study of Table I that the students in the various types of schools differ in intelligence level. For the I64 pupils in city high schools the median index of brightness (I. B.) is 100.5 ; that is, 0.5 above the norm given by the author. The same table shows the distribution of I. B.'s for the 290 pupils in the six affiliated and classified town schools. It will be seen that a median I. B. of 98 places this group 2.5 points below the median for the city group. The median I. B. for the 59 pupils in the unaffiliated small town schools is 84.4 , or 13.6 below that of the affiliated town schools and I6.I3 below that of the city schools. Finally, the median of 77 for the rural schools is 23.5 points below that of the city schools.

The gradual decrease in the median I. B., as shown above, indicates that urban pupils are more adept in answering the type of questions found in the Otis tests than are those living under more rural conditions. The results might possibly be invalidated to some extent by the small number of pupils shown. However, it is the opinion of the writer, based upon a long association with the pupils in these types of schools, that the medians would be changed very little if the numbers had been doubled or tripled. If the distributions for the third and fourth groups are combined as one unaffiliated rural-school group, a better distribution curve will result, without changing materially the conclusion reached. The difference can not be due to sex, since the number of boys and girls in each group is approximately equal. Nor can the results be due to the presence of foreign children. The city system and three of the affiliated town schools had, in fact, more than their share of the foreign element. One of the small town

\footnotetext{
* See references at end of article.
} 


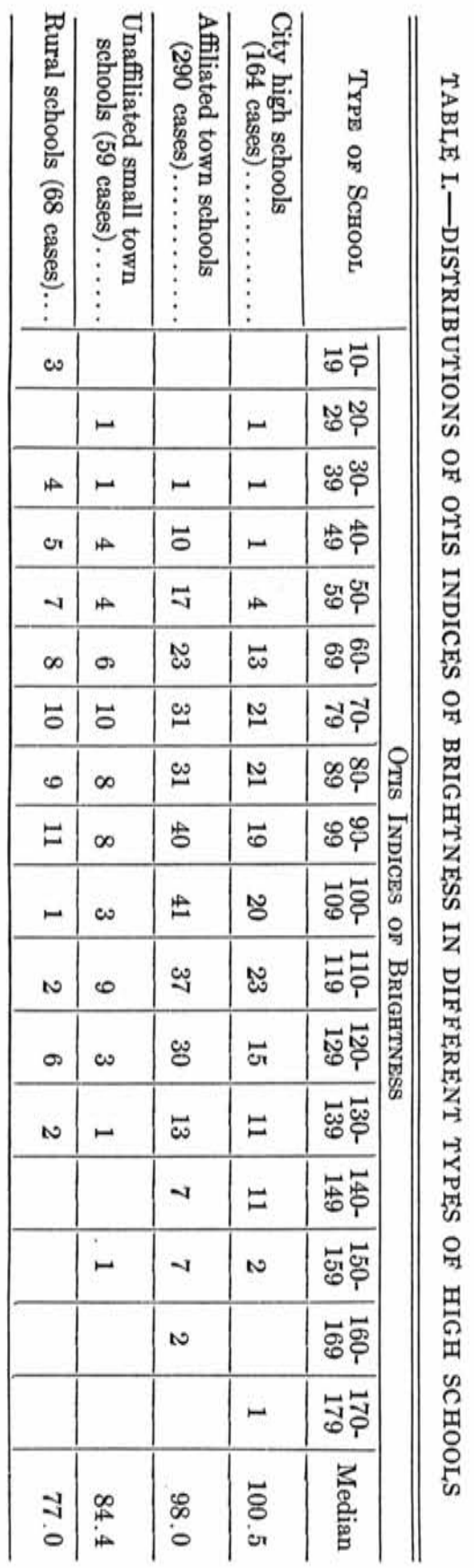


unaffiliated schools and two of the rural schools also had several immigrant pupils. It is clear, therefore, that the results could not have been materially affected from this source.

\section{Conclusions}

These tests represent as nearly average groups of students in each type of school as it was possible to obtain. This being the case, the conclusion seems to be justified that the country child is lower in general mentality, as measured by the group mental test, than the city child. In a recent study Colvin* concludes that no group mental test is an absolute measure of general intelligence. He does find, however, that results from the use of the Otis test are closely correlated with a child's ability to succeed in the average high-school subject. Proctor* and others have reached the same conclusion in similar investigations. The sociologist would perhaps argue that differences in social environment and training account for the fact that the country child is not as well prepared for attaining high marks in this kind of test as his city neighbor; that the test is not a true measure of native ability. It should not be forgotten, however, that for years there has been a steady migration of the country's best to the city. Lincolns come from the rural districts, but they never go back. All of the available evidence points to the conclusion that the mental traits, whatever they may be, which are measured by the Otis group tests, exist to a less degree in the average rural child than in the average child of the city.

Colvin* further points out in his study of the Otis test that the median scores derived in his investigation are much higher than the norms given by the author. It is evident from the above discussion that the type of school in which the tests were given might easily influence the results.

\section{REFERENCES}

Colvin, S. S. Some Recent Results Obtained from the Use of the Otis Intelligence Scale. Journal of Educational Research, Vol. III, January, 1921. Proctor, W. M. Use of Psychological Tests in Edueational Guidance of High School Pupils. Journal of Educational Research, Vol. I, May, 1920.

* See references. 
Thorndike, E. L. Nature and Measure of Intelligence. Journal of Educational Psychology, Vol. XII, March, 1921.

Colvin, S. S. Nature and Measure of Intelligence. Journal of Educational Psychology, Vol. XII, March, 1921.

Rugg, H. O. Statistical Method as Applied to Education.

Fordyce, Charles. Intelligence Tests in Classifying Children in Elementary Schools. Journal of Educational Research, Vol. IV, June, 1921.

Otis, A. S. Manual of Directions for Advanced Examination. 